\title{
„Workaholism“" does not always mean workaholism...? - about the controversial nomenclature in the research on work addiction ${ }^{1}$
}

\begin{abstract}
This article attempts to point out the main problem in research on workaholism, namely over-use of the term workaholism when describing symptoms or constructs which are not related to work addiction. Workaholism has one, negative pathological/dysfunctional form and can be differentiated from the healthy forms of over-engagement (e.g. work enthusiasm). Based on the analysis of one example of research results, this article explains that the nomenclature of „, workaholic" is not applicable to the case of over-engaged employees with healthy symptoms (e.g. high work involvement and work enjoyment and high or low satisfaction with life situation). The second aim of the article is to argue that the invalid conceptualisation and measurement of workaholism can result in conclusions which do not really regard work addiction.
\end{abstract}

Key words: workaholism, work addiction, nomenclature

\section{Introduction}

Over-use of the pathological term „workaholism“ to describe a person highly involved in work and with healthy symptoms has thus far been typical, mainly for popular knowledge. Some recent research examples show that this problem can also regard scientific knowledge on workaholism. This troubling state (because it represents potentially doubtful scientific knowledge) of over-using the term workaholism in scientific knowledge manifests, for example, by applying the term to constructs or dimensions that are not related to this phenomenon, like ,functional workaholism“ (Malinowska \& Tokarz, 2014) or „enthusiastic workaholism“ (e.g. Spence and Robbins, 1992; van Beek, Taris, \& Schaufeli, 2011).

Research results demonstrate that different forms of high work involvement exist, and show the empirical distinctiveness of the healthy form of over-engagement (enthusiasm) and the pathological one (workaholism) (e.g. Schaufeli, Taris, van Rhenen, 2008). Work enjoyment has been found to be the inherent feature of work engagement and as such has to be excluded as problematic from any conceptualization of workaholism (Schaufeli, Taris, Bakker, 2006; McMillan, O'Driscoll, Marsh, \& Brady, 2001; Mudrack, 2006; Porter, 2001). I strongly believe that subsuming different types of healthy employee overengagement under the same heading ("workaholism") is a maladaptive strategy because it blurs the real meaning of workaholism and adds to the conceptual confusion. Rather, I argue that the pathological form of over-working (workaholism) and the healthy forms (work engagement, other functional forms of over-engagement) are conceptually and empirically distinct and should be consistently treated as distinctive on three levels: its nomenclature, conceptualization, and measurement.

\section{Contemporary conceptualization of workaholism}

The term workaholism was adopted for describing the pathological, addictive form of over-engagement, and it has been recognized in most conceptualizations as the compulsion (irresistible inner drive) and/or uncontrollable need to work incessantly (e.g. McMillan, O'Driscoll, \& Burke, 2003; Oates, 1971; Porter, 1996). As Porter indicated (1996), workaholism should be interpreted as an addiction, excluding views that consider workaholism as a positive state (e.g. Machlowitz, 1980; Scott, Moore, \& Miceli, 1997; Spence \& Robbins, 1992). The majority of scholars who have been engaged in exploring workaholism for many years agree with this statement (e.g. Andreassen et al., 2014; Griffiths, 2005; Golińska, 2008, 2014; Robinson, 2007; Schaufeli, Taris \& van Rhenen, 2008; Paluchowski \& Hornowska, 2003, 2007; Sussman \& Sussman, 2011; Wojdylo, 2007, 2010a, 2010b, 2013).

However, it should be noted that up to now the leading concepts of workaholism have been concentrated

\footnotetext{
${ }^{1}$ This project was supported by Polish National Science Centre Grant (DEC/2011)/01/M/HS6/02567
} 
(conceptually and empirically) mainly on descriptive criteria of obsessive-compulsive components inherent in an addiction (e.g. Robinson, 2007; Schaufeli, Shimazu, et al., 2009; Spence \& Robbins, 1992). It should be remarked that obsession is not an addiction. As Wojdylo (2013) has argued, obsessive-compulsive tendencies are not sufficient to explain the addictive nature of workaholism because they neglect the main mechanism of work addiction, which is the compensatory function of emotions. Thus, concepts of workaholism based on obsessive mechanisms (e.g. Schaufeli, Taris \& van Rhenen, 2008) solely describe the obsessive-compulsive mechanisms of workaholism, but neglect the proper addictive mechanism and do not allow for workaholism to be measured as a real addiction. Only two empirically validated theories on workaholism which stress the addictive nature of workaholism currently exist. The theory of Griffiths concentrates on "surface" symptoms of work addiction (e.g. salience, tolerance, withdrawal symptoms) (Griffiths \& Karanika-Murray, 2012). In contrast to the theory of Griffiths, Wojdylo's theory of work craving draws attention to the mechanisms of work addiction: craving/desire for the compensatory function of emotions (relief, self-worth compensation), which explains the inner drive of workaholics to fulfill unrealistic standards of perfectionism (Wojdylo, 2013; Wojdylo et al., 2013; Wojdylo et al., 2014).

\section{Workaholism is a dysfunctional, pathological phenomenon}

Based on the analysis of recent research results (presented in the article: The structure of workaholism and types of workaholic, 2014; Malinowska \& Tokarz), it will be argued below that the nomenclature of ,workaholic“ is not applicable to the case of over-engaged employees with healthy symptoms (e.g. high work involvement and work enjoyment or low satisfaction with life situation). Next, the findings of this study also allow to explain that the invalid conceptualisation and inadequate measurement of workaholism can result in conclusions that do not regard work addiction.

Considering the above mentioned current knowledge about workaholism, assumptions and conclusions presented in the article (Malinowska \& Tokarz, 2014) raise considerable objections, which are listed and argued below.

(1) It is hard to follow the thesis presented in the article that considers workaholism as a positive phenomenon to be one of the current ways to define workaholism. This perspective and nomenclature (,positive workaholism“) is outdated, comes from the 80 's, and according to the current knowledge describes the phenomenon known as work enthusiasm. Thus, all the concepts of workaholism defined as positive phenomenon (coming mainly from the 80 's) do not regard (in the strict sense) workaholism, but work engagement. The analysis of research from the 80 's and the indicators used to measure "workaholism" therein allows us to recognize that the authors described this phenomenon using indicators of work enthusiasm and not workaholism.
For example, the phenomenon was described as "devotion to work" (Cantarow, 1979), "the inner need to work hard and for long hours by deriving real pleasure from work" (Machlowitz, 1980), or a "high level of involvement in work and deriving a lot of satisfaction from work" (Naughton, 1987). In the 80's workaholism or work obsession was not yet differentiated from work enthusiasm. Only later studies showed (Schaufeli et al., 2008) that work obsession and work engagement are different constructs that can also be discriminated empirically.

(2) Conceptualization of workaholism: The conceptualization of workaholism proposed by $\mathrm{Ng}$ et al. (2007) was adopted in the research. Taking into consideration the type of indicators of alleged workaholism, the conceptualization of workaholism used by $\mathrm{Ng}$ et al. (2007) does not regard real workaholism. The dimensions, such as work satisfaction or work hours, are not reliable indicators of workaholism/work addiction. Thus, the two dimensions in $\mathrm{Ng}$ et al.' $\mathrm{s}$ (2007) conceptualization of workaholism, i.e. the behavioral dimension defined as devoting time predominantly to work, and affective dimension defined as positive emotions related to work, are not adequate to diagnose workaholics. These symptoms are namely not typical for mechanisms of addiction. These dimensions (contrary to what the authors claim) are not based on addiction research. Devoting time predominantly to work and limiting time for other activities or positive emotions related to work (like satisfaction and pleasure) are dimensions typical of work enthusiasts and describe healthy (and not addictive) mechanisms of personality. As will be argued below, the findings of the study by Malinowska and Tokarz (2014) confirm that the conceptualization of "workaholism" presented in the article does not really regard workaholism.

(2) Operationalization: Nine indicators were used in the study to measure "workaholism" and they were integrated into three dimensions: behavioral (e.g. time spent working), cognitive (e.g. drive to work), and affective (e.g. work enjoyment) (Figure 2). The controversial conceptualization assumed in the article considers workaholism as a phenomenon with both positive (healthy) and negative (pathological) components. The analysis of these variables shows that the model of alleged "workaholism" integrates variables that describe two different constructs, work enthusiasm and over-engagement (e.g. time spent working, work enjoyment, work involvement), with variables that describe workaholism (drive to work, lack of control over working). Argumentation for this proceeding, presented in the article like "the importance of taking both salutogenetic and pathogenetic perspectives into consideration when analyzing phenomena related to disorders" (p. 214) as the rationale for integrating healthy and pathological indicators for measuring/defining workaholism, is inconsistent with the clinical knowledge. Considering the clinical knowledge regarding the nature and diagnosis of disorders (ICD or DSM), this statement in the context of defining and measuring of disorders seems unfounded. It would namely imply the groundless argument that the salutogenetic perspective (healthy symptoms) should be taken into consideration by identifying criteria of disorders. The 
integration of salutogenetic and pathogenetic perspectives may indeed be applied, but in the field of prevention and treatment of the disorder (e.g. workaholism) and not in its diagnosis/recognition. The integration of healthy symptoms (typical for work enthusiasm) with pathological symptoms (typical for work addiction) in the diagnosis of the disorder (workaholism) is contrary to clinical knowledge.

On the level of nomenclature it means that the term workaholism is reserved for pathological forms of over-engagement, and concepts/terms like "functional workaholism" or "enthusiastic workaholism" are contrary to clinical knowledge and thus unvalid. By analogy to substantial addictions it would be asked, if we would agree with the analogous and equally groundless nomenclature like "functional alcoholism"?

In light of clinical knowledge, it is not acceptable to adopt the terminology "functional workaholism" and "dysfunctional workaholism", which is proposed in the article (The structure of workaholism and types of workaholic, 2014). Futhermore, the argumentation given in the article for creating the terms ("workaholism" and "dysfunctional workaholism"), based on analogy to the terms "perfectionism" and "neurotic perfectionism", forms additional substantiations against this proceeding and not for it. It is namely justified to form the term "pathological/ dysfunctional perfectionism" because the term perfectionism solely regards the healthy form of perfectionism and the attribute "neurotic" describes the pathological form of this phenomenon. But in contrary to the term perfectionism, the term workaholism solely regards pathological terminology. Thus, the attribute "functional workaholism" would imply the unacceptable, healthy form of disorder. In the analogy to the terminology of perfectionism and pathological perfectionism, it would be possible in the case of overengagement (nomenclature for healthy syndrome) to differ at the level of the terminology: over-engagement and the dysfunctional form of over-engagement.

\section{Types of workaholics may be only dysfunctional}

Following the above argumentation, the hypothesis presented in the article (p.215), regarding "functional and dysfunctional types of workaholic based on three workaholism dimensions" seems not valid because the model presented as "workaholism" in this research was not based on the conceptualization and operationalizing of real workaholism.

Also, it may be observed at the level of the study results that the findings have not confirmed the conceptualization of "workaholism" assumed in the article as a phenomenon with three positive correlated components: behavioral, cognitive, and affective (in the form of e.g. work enjoyment). As presented in Figure 2, study results showed that the explored construct has two components (behavioral and cognitive) that are positively correlated, but also two components (cognitive/compulsive and affective, e.g. work enjoyment) that are negatively correlated. The findings regarding the negative correlation between work compulsion and work enjoyment are consistent with the current knowledge regarding the distinctiveness of conceptually and empirically different constructs: workaholism and work enthusiasm. Thus, study results presented in the article reflect inconsistency and inaccuracy in the field of the conceptualized indicators of workaholism.

The received findings also undermine the legitimacy of distinguishing the postulated types of „workaholics“. Based on the study results, the authors conclude that two types of „workaholics“ exist: partially satisfied workaholics (cluster 1 in the study) and dissatisfied workaholics (cluster 3 in the study). This conclusion seems not to be confirmed by the findings.

As the study results indicate, respondents referred to as "partially satisfied workaholics" scored high on the behavioral dimension (e.g. time spent working) and high on the affective dimension (e.g. work enjoyment), and showed satisfaction with self- realization and general satisfaction with life (it is worthwhile to note here that all of these symptoms are indicators of work engagement) and at the same time they scored low on drive to work and the lack of control over working (these symptoms are indicators of workaholism). As these study results show, the group of respondents classified in the article as partially satisfied workaholics showed symptoms that are characteristic for work enthusiasts.

But in the article it is incomprehensibly concluded that because partially satisfied workaholics do not manifest satisfaction with life outside work (family, material situation, and health), they may not be regarded as engaged employees and should be called also workaholics. If, as the study results show, this group of respondents does not manifest drive to work or lack of control over working (symptoms which are typical for work addiction or work obsession), there is no reason to call them workaholics. Accordingly, if this group manifests only partially symptoms that are typical for work engagement (because of lack the satisfaction with life outside work), it seems more appropriate to define them as "partially satisfied enthusiasts" instead of partially satisfied workaholics.

Study results also showed that the group of respondents referred to as dissatisfied workaholics is the only group that can be classified as workaholics. This group scored above average namely in the cognitive dimension of workaholism (e.g. drive to work and lack of control over working), but at the same time scored below average in the behavioral and affective dimensions (indicators of work engagement). These results imply that the behavioral dimension (e.g. time spent working) and the affective dimension in the form of positive emotions do not really describe workaholics.

\section{Conclusions}

The current knowledge about workaholism calls for valid nomenclature, conceptualization, and measurement of this phenomenon. Some study results (like those discussed here) indicate that the conceptualization of "workaholism" that includes healthy symptoms of work engagement (e.g. work hours and work satisfaction) does not really regard 
workaholism because, as the study results show, these dimensions are not diagnostic for obsessive working people or work addicted, but typical for work engaged employees.

The analyzed study results showed that workaholism cannot be identified on the basis of positive emotions related to work or satisfaction with work. Moreover, it is noteworthy that the study results of Malinowska and Tokarz (2014) have not allowed for the distinction of the group of respondents with high drive to work and high work satisfaction (the type of respondents called "enthusiastic workaholics" by Spence and Robbins (1992) or van Beek, Taris, \& Schaufeli, 2011). Generally, the presented structure of the nine related factors in the article (Malinowska \& Tokarz, 2014) do not regard workaholism (work addiction), thus it seems unvalid to conclude that the study results describe workaholism.

Considering the typology of "workaholics", the obtained results indicate that real (dissatisfied) workaholics are highly driven to work, experience lack of control over working, and have low work satisfaction. The group of respondents that showed high time spent working and high work enjoyment manifested the symptoms that, according to the current knowledge are diagnostic for work enthusiasts and not for workaholics (Schaufeli et al., 2008; Wojdylo, 2013; Wojdylo et al., 2014). Thus, the form of high work involvement with high work enjoyment that is groundlessly called by some authors as a "functional workaholism" is indeed a form of work enthusiasm.

Work enthusiasts, like workaholics, also value work activity over other acitivities in their life, but this activity is not based on the mechanisms of addiction (e.g lack of control, tolerance) or obsession. For this reason, it is useful to reserve the term workaholism for the pathological, dysfunctional forms of over-engagement and not over-use it when describing the healthy forms.

In summary, with a sense of responsibility for development of the current scientific knowledge about workaholism, it is very important to consider in the case of each research study if the nomenclature (the used term) really describes the explored construct. Pushing the concept of workaholism to research phenomenons that are not related to workaholism may lead to much more confusion than better understanding of this phenomenon.

A more valid researching and better understanding of workaholism can be achieved if scholars would be able to differentiate between work addiction and other nonaddictive forms of overworking both at the level of the conceptualization and the measurement of the phenomenon.

\section{References}

Andreassen, C.S.; Griffiths, M.D.; Hetland, J.; Kravina, L.; Jensen, F.; Pallesen, S. (2014). The prevelance of workaholism: a survey study in a nationally representative sample of Norwegian employees. PLOS ONE, 9, 1-10.

Golińska, L. (2008). Pracoholizm. Uzależnienie czy pasja. Wydawnictwo Difin.

Golińska, L. (2014). Pracoholizm inaczej. Wydawnictwo Difin.

Griffiths, M. D. (2005b). Workaholism is still a useful construct. Addiction Research and Theory, 13, 97-100.

Griffiths, , M. D. \& Karanika-Murray, M. (2012). Contextualising overengagement in work: Towards a more global understanding of workaholism as an addiction. Journal of Behavioral Addictions, 1 (3), 87-95.

Machlowitz, M. (1980). Workaholics: Living with Them, Working with Them. Reading, MA: Addison-Wesley.

McMillan, L.H.W., O’Driscoll, M.P., Marsh, N.V., \& Brady, E.C. (2001). Understanding workaholism: Data synthesis, theoretical critique, and future design strategies. International Journal of Stress Management, 8, 69-91.

McMillan, L. H. W., O’Driscoll, M. P. \& Burke, R. J. (2003). Workaholism: A review of theory, research, and future direc- tions. In C. L. Cooper \& I. Robertson (Eds.), International Review of Industrial and Organizational Psychology (Vol. 18, pp. 167-190). New Jersey: John Wiley and Sons.

Mudrack, P. E. (2006). Understanding workaholism: The case of behavioral tendencies. In R. J. Burke (Ed.), Research companion to working time and work addiction (pp. 108-128). Cheltenham, UK: Edward Elgar.

Naughton, T. J. (1987). A conceptual view of workaholism and implications for career counselling and research. Career Development Quarterly, 5, 137-148.

Ng, T. W. H., Sorensen, K. L. \& Feldman, D. C. (2007). Dimen- sions, antecedents, and consequences of workaholism: A con- ceptual integration and extension. Journal of Organizational Behavior, 28, $111-136$.

Oates, W. (1971). Confessions of a Workaholic: The Facts about Work Addiction. New York: World.

Paluchowski, W. J. \& Hornowska, E. (2003). Pracoholizm a system wartości i uwarunkowania temperamentalne [Workaholism and values systems and temperamental determinants]. In S. A. Witkowski (Ed.), Psychologiczne wyznaczniki sukcesu w zarządzaniu. Tom IV (pp. 259319). Wrocław: Wydawnictwo Uniwersytetu Wrocławskiego.

Paluchowski, W. J. \& Hornowska, E. (2007). Praca - skrywana obsesja [Workaholism - the hidden obsession]. Poznań: Bogucki.

Porter, G. (1996). Organizational impact of workaholism: Suggestions for researching the negative outcomes of excessive work. Journal of Occupational Health Psychology, 1, 70-84.

Porter, G. (2001). Workaholic tendencies and the high potential for stress among co-workers. International Journal of Stress Management, 8 , $147-164$.

Schaufeli, W. B., Taris, T. W., \& Bakker, A. (2006). Dr. Jekyll and Mr. Hide: On the differences between work engagement and workaholism (pp. 193-217). In R. Burke (Ed.), Research companion to working time and work addiction. Northhampton, UK: Edward Elgar.

Scott, K. S., Moore, K. S. \& Miceli, M. P. (1997). An exploration of the meaning and consequences of workaholism. Human Relations, 50, $287-314$.

Spence, J. T. \& Robbins, A. S. (1992). Workaholism: Definition, measurement, and preliminary results. Journal of Personality Assessment, 58, 160-178.

Sussman S, Sussman AN (2011) Considering the definition of addiction. International Journal of Environmental Research and Public Health 8: 4025- 4038.

Van Beek, I., Taris, T. W., \& Schaufeli, W. B. (2011). Workaholic and work engaged employees: Dead ringers or worlds apart? Journal of Occupational Health Psychology, 16, 468-482. doi:10.1037/ a0024392

Wojdylo, K. (2007). Koncepcja osobowościowych wyznaczników pracoholizmu. [A conception of personal determinants of workaholism]. Studia Psychologiczne, 45, 53-67.

Wojdylo, K. (2010a). Funkcjonowanie pracoholików w sytuacji zadaniowej [Functioning of workaholics in the task situation]. Przegląd Psychologiczny, 53, 75-98.

Wojdylo, K. (2010b). Pracoholizm. Perspektywa poznawcza. [Workaholism. A cognitive perspective]. Warszawa, Poland: Difin.

Wojdylo, K. (2013). Work craving - teoria uzależnienia od pracy [Work craving - the theory of work addiction]. Nauka, 3, 87-97.

Wojdyło, K., Baumann, N., Buczny, J, Owens, G; Kuhl, J., (2013). Work Craving: A Conceptualization and Its Measurement. Basic and Applied Social Psychology, 35 (6), 547-568.

Wojdylo, K., Baumann, N., Fischbach L., \& Engeser, S. (2014). Live to Work or Love to Work: Self-regulation, Work Craving, and Work Enthusiasm. PLOS ONE. 